\title{
Production of cachama reciprocal hybrids in earth ponds
}

\author{
José Nobel Ramírez-Mora ${ }^{* *}$ (D) Manuel Crisostomo Useche ${ }^{1}$ Pedro Alexander Niño $^{1}$ \\ Carlos Leal $^{2}$ Bernardo Baldisserotto ${ }^{3}$ iD
}

${ }^{1}$ Estación Experimental de Piscicultura de Aguas Cálidas (EEPAC), Decanato de Investigación, Universidad Nacional Experimental del Táchira (UNET), 5001, San Cristóbal, Táchira, Venezuela. E-mail: jnobel@unet.edu.ve. "Corresponding author.

${ }^{2}$ Estudiante de Ingeniería de Producción Animal, Universidad Nacional Experimental del Táchira (UNET), San Cristóbal, Táchira,Venezuela. ${ }^{3}$ Departamento de Fisiologia e Farmacologia e Programa de Pós-graduação em Zootecnia, Universidade Federal de Santa María (UFSM), Santa Maria, RS, Brazil.

ABSTRACT: The growth of cachama hybrids, cachamoto (Colossoma macropomum $\bigcirc x$ Piaractus brachypomus $\hat{\delta}$ ) and cachamay (P. brachypomus o $x$ C. macropomum 3 ) was compared for 154 days to determine which showed the better productivity. The experiment was carried out in three earth ponds, each divided transversely with a plastic net, yielding six experimental units. Juveniles of cachamoto of $12.95 \pm 2.43 \mathrm{~g}$ and $6.75 \pm 0.42 \mathrm{~cm}$ and cachamay of $16.65 \pm 3.64 \mathrm{~g}$ and $7.41 \pm 0.62 \mathrm{~cm}$ were distributed in each sub-tank of $240 \mathrm{~m}^{2}$ at a density of $0.5 \mathrm{fish} \mathrm{m}^{-2}$. Fish were fed twice daily except on days when their weight and length, and the physical and chemical parameters of the water were measured. The following productive variables were evaluated: growth in weight and length, daily weight gain, daily feed intake, apparent feed conversion, specific growth rate, condition factor, productivity and the cost/benefit relationship. None of the analyzed variables presented statistical difference between treatments. Physical and chemical parameters of the water remained within the recommended values for cachama, and survival was 100\%. Based on the results obtained, it can be concluded that cachama reciprocal hybrids present a similar productive behavior, so that it is indifferent which one is chosen to be raised under the conditions evaluated.

Key words: black pacu, pirapitinga, fish culture, productivity, cost/benefit relationship.

Produção de híbridos recíprocos de tambaqui e pirapitinga em viveiros escavados

RESUMO: Comparou-se o crescimento de híbridos de tambaqui e pirapitinga, tambatinga (Colossoma macropomum 9 x Piaractus brachypomus $\widehat{\delta})$ e pirambaqui (P. brachypomus + + $x$ C. macropomum $\overrightarrow{0}$ ) durante 154 dias para se verificar qual deles apresentava melhor produtividade. $O$ experimento foi realizado em três viveiros de terra, cada um dividido transversalmente com uma rede plástica, originando

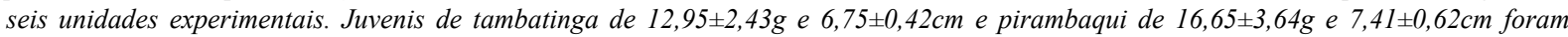
distribuidos em cada sub-tanque de $240 \mathrm{~m}^{2}$ em uma densidade de 0,5 peixe $\mathrm{m}^{-2}$. Os peixes foram alimentados duas vezes por dia, exceto nos dias em que se mediram peso, comprimento e parâmetros físicos e químicos da água. As variáveis produtivas avaliadas foram: crescimento em peso e comprimento, ganho de peso diário, consumo diário de alimento, conversão alimentar aparente, taxa de crescimento específico, fator de condição, produtividade e relação custo/beneficio. Nenhuma das variáveis analisadas apresentou diferença estatística entre os tratamentos. Os parâmetros físicos e químicos da água permaneceram dentro dos valores recomendados para tambaqui e pirapitinga e a sobrevivência foi de 100\%. Com base nos resultados obtidos, pode-se concluir que os híbridos de tambaqui e pirapitinga apresentam um comportamento produtivo semelhante, de modo que é indiferente qual deles é escolhido para ser criado nas condiçóes avaliadas.

Palavras-chave: tambatinga, pirambaqui, produtividade, piscicultura, relação custo/beneficio.

\section{INTRODUCTION}

The south western region of Venezuela presents edaphic, hydrological and climatic conditions appropriate for the farming of warmwater continental fish. Since 1986, numerous farms have been established for the farming of the cachamas Colossoma macropomum and Piaractus brachypomus, and in recent years, almost $100 \%$ of the farms grow the hybrid of these species; however, uncertainty remains as to which of the two groups of reciprocal hybrids shows the better yield. In terms of farming, the management of hybrids is performed in a manner similar to the pure species. Physical and chemical parameters of water, type and frequency of feeding and adaptation to the culture systems, among other conditions, are similar to parental groups (USECHE, 2001; GONZÁLEZ \& HEREDIA, 1989).

Similar to other species, the objective of producing hybrids of the two species of cachama present in Venezuela is to obtain individuals that show advantages of parents and that reflect in a higher productive yield. Several studies have analyzed the growth of these hybrids of cachama (BAUTISTA et al., 1999; SILVA-ACUÑA \& GUEVARA, 2002; BAUTISTA et al., 2005; ALENCAR-ARARIPE 
et al., 2011; LÓPEZ y ANZOÁTEGUI, 2012; UZCÁTEGUI-VARELA et al., 2014; GUEVARA et al., 2016). Maternal contribution to these reciprocal hybrids has not been genetically evaluated; but there may be a difference that could manifest in a higher offspring performance. In addition, due to large number of fish farmers and production of cachama hybrids, these fishes have social and economic important in the region. For this reason, the objective of this study was to evaluate the productive behavior of the reciprocal hybrids of cachamas raised in earth ponds.

\section{MATERIALS AND METHODS}

This study was performed at the Estación Experimental de Piscicultura de Aguas Cálidas (EEPAC) de la Universidad Nacional Experimental del Táchira (UNET). Cachamoto (Colossoma macropoтum \& $\mathrm{x}$ Piaractus brachypomus d) $(\mathrm{n}=360, \quad 12.95 \pm 2.43 \mathrm{~g}$ and $6.75 \pm 0.42 \mathrm{~cm})$ and cachamay (Piaractus brachypomus o $\mathrm{x}$ Colossoma macropomum $\left.\delta^{\Uparrow}\right)(\mathrm{n}=360,16.65 \pm 3.64 \mathrm{~g}$ and $7.41 \pm 0.62 \mathrm{~cm}$ ) were obtained by artificial reproduction induced by carp pituitary extract.

\section{Experimental design}

Three earth ponds of $480 \mathrm{~m}^{2}$ each were divided transversely with plastic mesh of $3.81 \mathrm{~cm}$, generating two experimental units per pond, and three replicas per treatment. In each of them, both groups were placed in completely randomized blocks and no water exchange was made, except replacement by evaporation. The trial lasted 154 days between March and August 2015. Fish were fed twice a day (8:00 a.m. and 4:00 p.m.), except on the sampling days, using commercial extruded feed of $28 \%$ crude protein (CP) for the first 60 days and then $24 \% \mathrm{CP}$ up to the end of the trial. The amount of food supplied was adjusted according to the biomass calculated in the samplings. The water quality parameters were measured every 28 days in each pond: temperature, transparency, dissolved oxygen, $\mathrm{pH}$, alkalinity and hardness using a Pionner multiparameter probe (Pioneer 65 multi meter, France), Secchi disk and a colorimetric water kit (Fresh Water Aquaculture Outfit, Lamotte, USA).

\section{Evaluation of productive and economic parameters}

Samples were taken every 14 days of $15 \%(\mathrm{n}=18$ fish $)$ of each replicate ( $\mathrm{n}=3$ replicates), registering weight and length with a digital scale (Ohaus Scout Pro) and an ichthyometer, respectively. However, at the end of the experiment the total number of remaining fishes was counted to calculate survival. Productive variables were calculated at the end of the test: weight gain [Wg: (final weight initial weight], length gain [Lg: (final length - initial length]; daily weight gain [DWg: (final weight-initial weight)/days of the production cycle], individual feed consumption [IFC: (total feed intake/total number of animals)]; food consumption rate [FCR: food consumption/total weight gain]; specific growth rate [SGR: ((Ln final weight - Ln initial weight)/time between measurements) $\times 100]$; condition factor [Kn: real weight/weight estimated by weight - ratio $\left.^{b}\right]$ (LE CREN, 1951), survival rate [SR: (number of individuals harvested/initial number of individuals) $\times$ 100]; productivity [PROD: (final biomass/surface of the experimental unit)] and benefit/cost ratio [I-C: (income/costs)].

\section{Statistical analysis}

A mixed effects model for repeated measures was adjusted. A different unstructured covariance was assumed for each individual, assuming that the intercept is different for each one (random intercept). Data were reported as mean \pm standard deviation. In order to analyze the effects of the treatments, one analysis of variance (ANOVA) of a GLM-type was performed, verifying previously the assumption of variance homogeneity (Barlett's test). The significance criterion was $\mathrm{P}<0.05$. Statistical analyses were performed using the SAS 8.2 program (SAS Institute Inc.).

\section{RESULTS}

Values obtained for the water physical and chemical variables (Table 1) correspond to both treatments because in each pond there was a replicate of each group. The length/weight ratio was directly proportional for both treatments, which presented the same value of the determination coefficient $\left(\mathrm{r}^{2}\right.$ $=0.996)$. Similarly, the growth coefficient (b) had a value close to three (3) (Figure 1). An increase of weight and length was observed in both treatments, but there were no statistical differences $(\mathrm{P} \geq 0.05)$. There were also no statistical differences $(P \geq 0.05)$ in productive and economic parameters evaluated (Tables 2 and 3).

\section{DISCUSSION}

In the commercial production of fish, one pursues optimization of the productive yield; for this reason, in the present study hybrids have been managed keeping water quality conditions 
Table 1 - Overall values of physical and chemical parameters of the water of the earth ponds for the culture of cachama reciprocal hybrids.

\begin{tabular}{lccccccc}
\hline Day & $\mathrm{T}\left({ }^{\circ} \mathrm{C}\right)$ & $\begin{array}{c}\mathrm{TRANSP} \\
(\mathrm{cm})\end{array}$ & $\begin{array}{c}\mathrm{DO} \\
\left(\mathrm{mg} \mathrm{L}^{-1}\right)\end{array}$ & $\mathrm{CO}_{2}\left(\mathrm{mg} \mathrm{L}^{-1}\right)$ & $\mathrm{pH}$ & $\begin{array}{c}\mathrm{ALC}\left(\mathrm{mg}^{-}\right. \\
\left.\mathrm{CaCO}_{3} \mathrm{~L}^{-1}\right)\end{array}$ \\
\hline 0 & $27.27 \pm 0.40$ & $28.67 \pm 2.08$ & $6.0 \pm 0.20$ & $11.67 \pm 2.89$ & $6.90 \pm 0.10$ & $17.1 \pm 0.00$ & $\begin{array}{c}\mathrm{H} \\
\left(\mathrm{mg} \mathrm{CaCO}_{3} \mathrm{~L}^{-1}\right)\end{array}$ \\
\hline 28 & $30.03 \pm 0.42$ & $28.33 \pm 1.53$ & $6.4 \pm 0.35$ & $10.00 \pm 0.00$ & $6.83 \pm 0.12$ & $22.8 \pm 9.87$ & $28.5 \pm 9.87$ \\
56 & $29.20 \pm 0.26$ & $30.67 \pm 1.53$ & $5.9 \pm 0.17$ & $13.33 \pm 2.89$ & $7.07 \pm 0.06$ & $22.8 \pm 9.87$ & $22.8 \pm 9.87$ \\
84 & $28.93 \pm 0.25$ & $27.67 \pm 1.15$ & $6.07 \pm 0.15$ & $11.67 \pm 2.89$ & $6.9 \pm 0.10$ & $28.5 \pm 9.87$ & $22.8 \pm 9.87$ \\
112 & $28.10 \pm 0.17$ & $30.33 \pm 2.08$ & $6.10 \pm 0.20$ & $13.33 \pm 2.89$ & $7.03 \pm 0.21$ & $22.8 \pm 9.87$ & $22.8 \pm 9.87$ \\
140 & $28.40 \pm 0.36$ & $27.67 \pm 2.52$ & $5.97 \pm 0.31$ & $11.67 \pm 2.89$ & $6.97 \pm 0.06$ & $28.5 \pm 9.87$ & $22.8 \pm 9.87$ \\
mean & $28.66 \pm 0.94$ & $28.72 \pm 2.14$ & $6.07 \pm 0.26$ & $11.94 \pm 2.51$ & $6.95 \pm 0.13$ & $23.75 \pm 8.58$ \\
\hline
\end{tabular}

Mean \pm standard deviation $(n=6) . T$ - temperature, TRANSP - transparency, OD - dissolved oxygen, ALC - alkalinity, H - hardness.

similar to the natural environment. Values of the physical and chemical parameters measured in the ponds of the present experiment were within the desired ranges (GONZÁLEZ \& HEREDIA, 1998); however, temperature, transparency, alkalinity and hardness sometimes presented values slightly outside the suggested range, apparently without affecting performance at such times.

The value of the correlation coefficient of the relationship between length and weight for

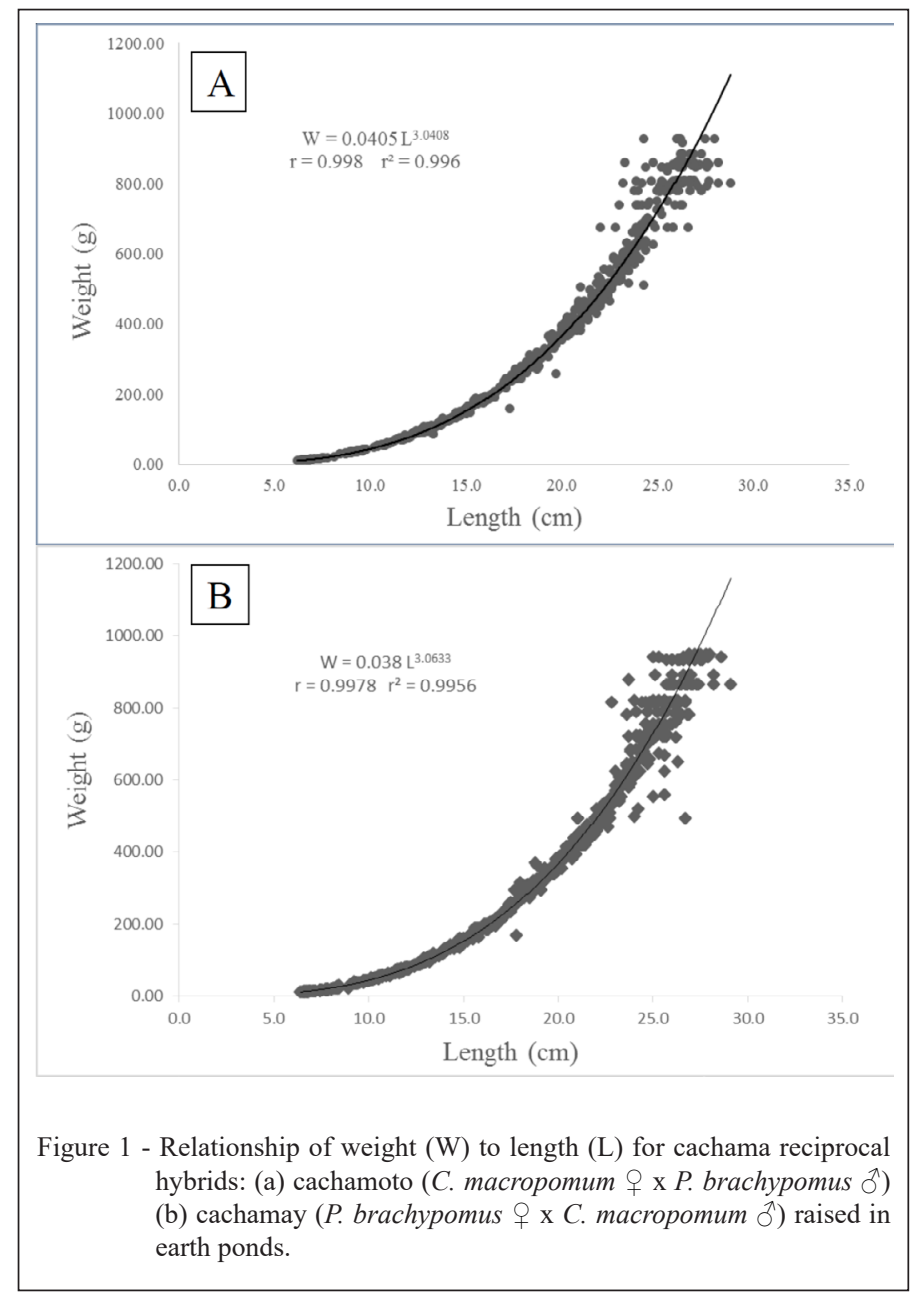

Ciência Rural, v.49, n.11, 2019. 
Table 2 - Growth performance of cachama reciprocal hybrids in earth ponds.

\begin{tabular}{|c|c|c|}
\hline \multirow[t]{2}{*}{ VARIABLE } & \multicolumn{2}{|c|}{ 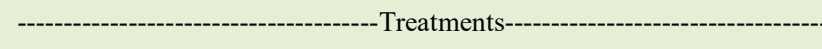 } \\
\hline & CACHAMOTO & CACHAMAY \\
\hline Fish number & 360 & 360 \\
\hline Initial weight (g) & $12.95 \pm 2.43$ & $16.65 \pm 3.64$ \\
\hline Final weight $(\mathrm{g})$ & $847.68 \pm 32.36$ & $892.59 \pm 47.71$ \\
\hline Weight gain $(\mathrm{g})$ & $834.74 \pm 18.08$ & $875.94 \pm 9.64$ \\
\hline Initial length $(\mathrm{cm})$ & $6.76 \pm 0.42$ & $7.41 \pm 0.62$ \\
\hline Final length $(\mathrm{cm})$ & $26.43 \pm 1.01$ & $26.74 \pm 0.94$ \\
\hline Length gain $(\mathrm{cm})$ & $19.67 \pm 0.16$ & $19.33 \pm 0.36$ \\
\hline Daily weight gain (g) & $5.42 \pm 0.12$ & $5.69 \pm 0.06$ \\
\hline Individual food consumption (g) & $1554.32 \pm 27.19$ & $1464.37 \pm 12.56$ \\
\hline Feed conversion rate & $1.86 \pm 0.73$ & $1.67 \pm 0.42$ \\
\hline Specific growth rate $\left(\%\right.$ day $\left.^{-1}\right)$ & $2.716 \pm 0.039$ & $2.586 \pm 0.036$ \\
\hline Condition factor & $1.015 \pm 0.010$ & $1.020 \pm 0.004$ \\
\hline Survival rate $(\%)$ & 100 & 100 \\
\hline
\end{tabular}

Mean \pm standard deviation ( $\mathrm{n}=3$ replicates, 18 fish sampled in each replicate). No significant difference between treatments.

both hybrids was close to $1.00(\mathrm{r}=0.998)$, which demonstrated a strong relationship between these two variables. In addition, the value of the growth coefficient (b) obtained suggests that the growth was isometric (SANTOS-SANES et al., 2006), similar to that reported by PRADA (1982) in C. macropomum. Other experiments using higher stocking densities described minor allometric growth: PASQUIER et al. (2011) reported $2.3(\mathrm{r}=0.96)$ for $C$. macropomum raised in cages and an experiment in tanks obtained values of 2.7-2.93 for cachamoto (BAUTISTA et al., 2005), while for P. brachypomus POLEO et al. (2011) reported values of $3.4379\left(\mathrm{r}^{2}=0.9517\right)$ and $3.5843\left(r^{2}=0.9823\right)$.

Values of $\mathrm{Wg}$ and DWg observed in the present study were lower than those reported by SILVA-ACUÑA and GUEVARA (2002) (initial weight $123 \mathrm{~g}$ ) with cachamoto in earth ponds: 1579-1726g and 10.69-11.50g day ${ }^{-1}$; respectively, and also by MARCOS et al. (2016) (initial weight $65.4 \mathrm{~g}$ ) with genetically selected C. macropomum in earth ponds: $1465-1947 \mathrm{~g}$ and $6.29-9.06 \mathrm{~g} \mathrm{day}^{-1}$ in earth ponds However, these values were higher than those observed by PASQUIER et al. (2011) (initial weight $3.0 \mathrm{~g}$ ) with $C$. macropomum in glass fiber tanks: $752.6 \mathrm{~g}$ and $3.53 \mathrm{~g}$ day $^{-1}$, respectively, LÓPEZ and ANZOÁTEGUI (2012) (initial weight 3.4g) with cachamoto in masonry tanks: $460.2 \pm 32.0 \mathrm{~g}$ and $2.99 \pm 0.21 \mathrm{~g} \mathrm{day}^{-1}$, by UZCÁTEGUI-VARELA et al. (2014) (initial weight $14.8 \mathrm{~g}$ ) with cachamay in masonry tanks: $0.87 \pm 0.02-1.68 \pm 0.02 \mathrm{~g} \mathrm{day}^{-1}$, and by CRUZ-VELÁSQUEZ et al. (2014) (initial weight $82.8 \mathrm{~g}$ ) with $P$. brachypomus in earth ponds: $3.42 \mathrm{~g}$ day $^{-1}$. The SGR verified in the present study was similar to C. macropomum: $2.6 \%$ day $^{-1}$ (PASQUIER et al., 2011), but lower than that reported by LÓPEZ and ANZOÁTEGUI (2012): $5.89 \pm 0.21 \%$ day $^{-1}$, and higher than that reported by UZCÁTEGUI-VARELA et al. (2014): $0.5 \pm 0.12-0.85 \pm 0.15 \%$ day $^{-1}$.

The FCR observed in the present study was similar to those verified in $C$. macropomum (1.72 and 1.78) (PASQUIER et al., 2011; LÓPEZ and ANZOÁTEGUI, 2013), P. brachypomus (1.5-1.6) (POLEO et al., 2011) and cachamoto (1.6) (LÓPEZ and ANZOÁTEGUI, 2012). However, other studies showed different FCR values for cachamoto (0.97-1.1 and 2.7-2.8) (SILVA-ACUÑA \& GUEVARA, 2002; BAUTISTA et al., 2005; ALENCAR-ARARIPE et al., 2011) and cachamay (2.1-3.54) (UZCÁTEGUIVARELA et al., 2014).

Value of Kn indicated the degree of wellbeing of an individual or population in a given environment and is related to the growth rate and comfort level of the animals (LE CREN, 1951), where: $\mathrm{Kn} \geq 1=\operatorname{good}$ and $\mathrm{Kn} \leq 1=\operatorname{bad}(\mathrm{LECREN}, 1951)$. An isometric growth of the population associated with values close to ' 1 ' for Kn would indicate good growing conditions in an evaluated population (HABIT, 2005). The Kn values obtained in the present study were close to ' 1 ', which indicated that both groups presented good physiological condition. Values of survival achieved (100\%) reinforce this 
Table 3 - Economic variables resulting from the culture of cachama reciprocal hybrids in earth ponds.

\begin{tabular}{|c|c|c|}
\hline \multirow[t]{2}{*}{ VARIABLE } & \multicolumn{2}{|c|}{ 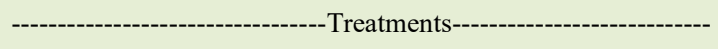 } \\
\hline & CACHAMOTO & CACHAMAY \\
\hline \multicolumn{3}{|c|}{ - } \\
\hline Seeded fish $(\mathrm{N})$ & 360 & 360 \\
\hline Culture area $\left(\mathrm{m}^{2}\right)$ & 720 & 720 \\
\hline Stocking density (fish $\mathrm{m}^{-2}$ ) & 0.5 & 0.5 \\
\hline Initial mean weight $(\mathrm{g})$ & 12.95 & 16.65 \\
\hline Initial biomass (kg) & 4.662 & 5.994 \\
\hline Harvested fish (N) & 360 & 360 \\
\hline Final average weight (g) & 847.68 & 892.59 \\
\hline Final biomass (kg) & 305.17 & 321.33 \\
\hline Biomass increase $(\mathrm{kg})$ & 300.52 & 315.34 \\
\hline Feed conversion rate & 1.86 & 1.67 \\
\hline Production $\left(\mathrm{kg} \mathrm{Ha}^{-1}\right)$ & 4238.47 & 4462.92 \\
\hline Culture time (days) & 154 & 154 \\
\hline Productivity $\left(\mathrm{kg} \mathrm{Ha}^{-1}\right.$ year $\left.^{-1}\right)$ & 10045.73 & 10577.7 \\
\hline Assay productivity $\left(\mathrm{kg} \mathrm{m}^{-2}\right)$ & 0.42 & 0.44 \\
\hline \multicolumn{3}{|c|}{ - } \\
\hline Cost per fish (Bs 20.00 unit $\left.^{-1}\right)$ & 7200.00 & 7200.00 \\
\hline Food supplied (kg) & 558.967 & 526.622 \\
\hline Cost per food (Bs $\left.1008.00 \mathrm{~kg}^{-1}\right)$ & $563,438.94$ & $530,834.78$ \\
\hline Disinfectant cost (cal: Bs $345.00 \mathrm{~kg}^{-1}$ ) & $69,000.00$ & $69,000.00$ \\
\hline Maintenance of equipment (pump) & $20,000.00$ & $20,000.00$ \\
\hline Labor (Bs. 7,000.00 day ${ }^{-1}$ x10.5) & $73,500.00$ & $73,500.00$ \\
\hline Subtotal & $733,138.94$ & $700,534.78$ \\
\hline \multicolumn{3}{|c|}{ 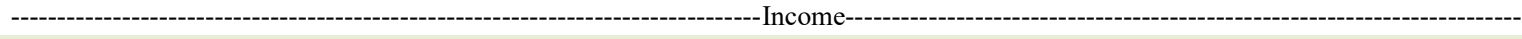 } \\
\hline Net culture yield $(90 \%)(B s)$ & 274.653 & 289.197 \\
\hline Harvest value (Bs. $\left.3,400.00 \mathrm{~kg}^{-1}\right)$ & $933,820.20$ & $983,269.80$ \\
\hline Benefit/cost ratio & 1.27 & 1.40 \\
\hline
\end{tabular}

Bs - Venezuelan bolivar. Prices updated to January 2017. Official dollar value (SIMADI Rate) 1US\$= Bs. 674.37; Unofficial dollar value 1US\$ $=$ Bs. 3156.47. No significant difference between treatments.

idea, allowing to infer a good degree of well-being and comfort of the fish throughout the experiment, probably due to the low stocking density used. In commercial cultures of cachamas and their hybrids, survival problems have been observed as the stocking density increases. Experiments with cachama hybrids using similar culture conditions yielded 91.6-100\% survival (SILVA-ACUÑA \& GUEVARA, 2002; LÓPEZ \& ANZOÁTEGUI, 2012; UZCÁTEGUIVARELA et al., 2014).

Productivity achieved in the present study was similar to those obtained in traditional systems (LÓPEZ \& ANZOÁTEGUI, 2012; UZCÁTEGUIVARELA et al., 2014). Another experiment raising cachamoto in earth tanks obtained productivities of 0.61 and $0.50 \mathrm{~kg} \mathrm{~m}^{-2}$, but lower $\mathrm{Wg}, \mathrm{DWg}$ and SGR values (SILVA-ACUÑA \& GUEVARA, 2002). These higher values compared to the present study are probably due to the fact that they used fish with greater initial weight $(123 \pm 0.9 \mathrm{~g})$. In a non-traditional system of farming (high density tanks), PASQUIER et al. (2011) reported higher productivity $\left(2.14 \mathrm{~kg} \mathrm{~m}^{-2}\right)$ in C. macropomum, but with lower values of $\mathrm{Wg}$, DWg and SGR.

\section{CONCLUSION}

Results of the present study demonstrated that both hybrids have similar growth and productivity yield. Consequently, we do not suggest a preference for the raising of either of them. 


\section{ACKNOWLEDGEMENTS}

The authors thank the UNET Research Dean of UNET for financial support; the technical staff of UNET and EEPAC for logistical support; and Professors Alexis Valery and Rossana Timaure of the Laboratorio de Instrumentación Biológica of UNET for their support in the statistical analysis. B. Baldisserotto was a recipient of a Conselho Nacional de Desenvolvimento Tecnológico (CNPq, Brazil) research fellowship.

\section{DECLARATION OF CONFLICT OF} INTERESTS

The authors declare no conflict of interest. The founding sponsors had no role in the design of the study; in the collection, analyses, or interpretation of data; in the writing of the manuscript, and in the decision to publish the results.

\section{AUTHORS' CONTRIBUTIONS}

JNRM, MCU and PAN conceived and designed experiments. JNRM, MCU, PAN and CL performed the experiments. JNRM performed statistical analyses of experimental data. JNRM and BB prepared the draft of the manuscript. All authors critically revised the manuscript and approved of the final version.

\section{REFERENCES}

ALENCAR-ARARIPE, M. et al. Threonine: lysine relation for tambatinga fingerlings. Boletim do Instituto de Pesca, v.37, n.4, p393-400, 2011. Available from: <ftp://ftp.sp.gov.br/ ftppesca/37_4_393-400.pdf.>. Accessed: Dec. 13, 2015.

BAUTISTA, E. et al. Utilización de la pulpa de café ensilada y deshidratada en la alimentación de cachamay. In: RAMÍREZ, J. Pulpa de café ensilada, producción, caracterización y utilización en la alimentación animal. San Cristóbal: Universidad Nacional Experimental del Táchira, 1999. p.109-135.

BAUTISTA, E. et al. Pulpa ecológica de café ensilada en la alimentación de alevines del híbrido cachamay (Colossoma macropomum x Piaractus brachypomus). Revista Científica, FCV-LUZ, v.XV, n.1, p.33-49, 2005. Available from: <http:// www.produccioncientifica.luz.edu.ve/index.php/cientifica/article/ view/15098/15075> Accessed: Sep. 13, 2017.

CRUZ-VELÁSQUEZ, Y. et al. On-farm evaluation of cachama blanca and Nile tilapia fed fermented aquatic plants in a polyculture. Orinoquia, v.18, n.2, p.269-277, 2014. Available from: <http://orinoquia.unillanos.edu.co/index.php/orinoquia/ article/view/386/992>. Accessed: May, 5, 2018.

GONZÁleZ, J.; HEREDIA, B. El cultivo de la cachama (Colossoma macropomum). 2 ed. Maracay: Fondo Nacional de Investigaciones Agropecuarias, 1989. 134p.

GUEVARA, L. et al. Evaluación del crecimiento de híbrido de peces "cachamoto" (Colossoma macropomum x Piaractus brachypomus) con alimento comercial y alternativo. Novum Scientiarum, v.2, p.10-24, 2016. Available from: $<\mathrm{http}: / / \mathrm{www}$. ecoambienteydesarrollo.org/revista/ojs/index.php/novum/article/ view/48/cachamotos2>. Accessed: Sep. 13, 2017.

HABIT, E. Aspectos de la biología y hábitat de un pez endémico de Chile en peligro de extinción (Diplomystes nahuelbutaensis Arratia, 1987). Interciencia, v.30, p.1-8, 2005.
LE CREN, E. D. The length-weight relationship and seasonal cycle in the gonad weight and condition in the perch, Perca fluviatilis. Journal of Animal Ecology, v.20, n.2, p.201-219, 1951. Available from: < https://www.jstor.org/stable/pdf/1540.pdf $>$. Accessed: Sep. 13, 2017.

LÓPEZ, P.; ANZOÁTEGUI, D. Crecimiento del hibrido cachamoto (Colossoma macropomum $x$ Piaractus brachypomus) en un sistema de recirculación de agua. Revista Zootecnia Tropical, v.30, n.4, p.345-342, 2012. Available from: <http://www.sian.inia.gob.ve/ revistas_ci/ZootecniaTropical/zt3004/pdf/zt3004_lopez_p.pdf $>$. Accessed: Sep. 13, 2017.

LÓPEZ, P.; ANZOÁTEGUI, D. Engorde de la cachama (Colossoma macropomum, CUVIER, 1816) cultivada en un sistema de recirculación de agua. Revista Zootecnia Tropical, v.31, n.4, p.271-277, 2013. Available from: <http://sian.inia.gob. ve/revistas_ci/ZootecniaTropical/zt3104/pdf/zt3104_lopez.pdf $>$. Accessed: Sep. 13, 2017.

MARCOS, R. et al. Weight gain and morphometric growth of genetically improved tambaqui (Colossoma macropomum). Semina: Ciências Agrárias, v.37, n.4, p.2521-2527, 2016. Available from: $<$ http://www.redalyc.org/pdf/4457/445746893022. pdf $>$. Accessed: May, 5, 2018.

PASQUIER, G.A.; et al Engorde experimental de cachama (Colossoma macropomum) en la estación Local El Lago, estado Zulia, Venezuela. Revista Zootecnia Tropical, v.29, n.2, p.213218, 2011. Available from: http://www.bioline.org.br/pdf?zt11019. Accessed: Sep. 13, 2017.

POLEO, G. et al. Cultivo de cachama blanca en altas densidades y en dos sistemas cerrados. Pesquisa Agropecuária Brasileira, v.46, n.4, p.429-437, 2011. Available from: <http://www.scielo.br/ pdf/pab/v46n4/13.pdf $>$. Accessed: Sep. 13, 2017.

PRADA, N. Densidades y niveles de suministros de alimento en el cultivo de cachama Colossoma macropomum (Cuvier) 1818. Bioagro, v. II, n.1, p.7-26, 1982.

SANTOS-SANES, I. et al. Relaciones talla-peso del barbul (Pimelodus clarias f.c. Bloch, 1785) en la cuenca del rio Sinú, Colombia. Revista MVZ Córdoba, v.11, p.62-70, 2006. Available from: <http://revistas.unicordoba.edu.co/index.php/revistamvz/ article/view/1045/1278 >. Accessed: Sep. 13, 2017.

SILVA-ACUÑA, A.; GUEVARA, M. Evaluación de dos dietas comerciales sobre el crecimiento del híbrido de Colossoma macropomum x Piaractus brachypomus. Revista Zootecnia Tropical, v.20, p.449-459, 2002. Available from: <http://mutante. inia.gob.ve/revistas_ci/ZootecniaTropical/volumen_20.htm $>$. Accessed: Sep. 13, 2017.

USECHE, M. El cultivo de la cachama, manejo y producción. Taller Actualización en Acuicultura. Universidad Nacional Experimental del Táchira. San Cristóbal, Estado Táchira, Venezuela, 2001.

UZCÁTEGUI-VARELA, J.P. et al. Evaluación de dietas con diferente contenido proteico sobre el desempeño productivo de alevines del híbrido cachamay (Colossoma macropomum $\mathrm{x}$ Piaractus brachypomus) en condiciones de cautiverio. Revista Científica, v.25, p.458-465, 2014. Available from: <http:// www.redalyc.org/articulo.oa?id=95932260011>. Accessed: Jul. 19, 2017. 